\title{
A case report: orbital myiasis
}

\author{
Choudhari P. ${ }^{1}$, Naik V. ${ }^{2}$, Raiturcar T. ${ }^{3}$, Usgaonkar U. ${ }^{4}$ \\ ${ }^{1}$ Dr. Priyanka Choudhari, Third Year Junior Resident, ${ }^{2}$ Dr. Vishaka Naik, Senior Resident, ${ }^{3}$ Dr. Tanvi Raiturcar, Senior \\ Resident, ${ }^{4}$ Dr. Ugam Usgaonkar, Professor and the Head; all authors are attached with department of Ophthalmology, \\ GMC, Bambolim, Goa, India.
}

Corresponding Author: Dr. Priyanka Choudhari, Junior Resident, Department of Opthalmology, GMC, Bambolim, Goa, India. E-mail: piyachoudhari15091986@gmail.com

\begin{abstract}
The aim of the present study was to report a rare case of orbital myiasis. Myiasis is the invasion of living animal tissue by a fly larvae (maggots). Larvae lay eggs which develop into future larvae and increase the destruction of tissues. Orbital involvement occurs in 5\% of all cases of myiasis. It is common in tropical countries with low standards of hygiene. The patient 70-year-old male was admitted to the hospital GMC, Bambolim, Goa on $6^{\text {th }}$ of February 2019 with pain and bleeding from his right eye for last 8 days with necrotized orbital tissue with several attached larvae. Patient underwent orbital wound tissue debridement and 82 larvae were removed and kept in turpentine solution; thorough saline wash was given. Systemic analgesics and antibiotics were given and as wound showed signs of healing on day 5 of admission patient was discharged. Infestations of orbital and ocular tissue by a fly larvae (Ophthalmo-myiasis) progresses rapidly and can completely destroy orbital tissue within days, most commonly seen in old debilitated patients with psychiatric illness and most commonly associated with eyelid tumors and should be treated promptly.
\end{abstract}

Key words: Myiasis, orbital myiasis, Ophthalmo-myiasis

\section{Introduction}

Myiasis is the invasion of living animal tissue by fly larvae (maggots). Orbital myiasis or ocular myiasis is the term when larvae infest the eye. Ocular involvement is seen in $5 \%$ of cases [1]. It is common in tropical countries with low standards of hygiene. Human ocular myiasis was first reported by Keyt in 1900 and later from India by Elliot in 1910 [2, 3]. Most commonly seen in elderly debilitated patients and the patients with psychiatric illness. Adult flies are non-parasitic, but their larvae can penetrate the intact skin and conjunctival mucus membrane.

Larvae lay eggs which develop into future larvae and increase the destruction of tissues.

\section{Case Report}

The patient 70-year-old male was admitted to the hospital GMC, Bambolim, Goa on $6^{\text {th }}$ February, 2019 with pain and bleeding from his right eye since 8 days with necrotized right orbital tissue with several attached live larvae. Part of lower eyelid was destroyed.

Patient had a history of self-fall causing head injury along with right eye injury twice over last 15 days with a gap of a week for which patient showed to a local private practitioner and treated, however patient was not compliant to the treatment; personal hygiene, wound hygiene was not maintained as patient lives alone and seems depressed.

Patient's visual acuity in both eyes was finger counting 1 meter and lens was found to be cataractous bilaterally. Patient was also found to be having a chronic subdural hemorrhage in fronto-temporo-parietal region on right side and intact globe on CT orbit.

Manuscript received: $14^{\text {th }}$ September 2019

Reviewed: $24^{\text {th }}$ September 2019

Author Corrected: $30^{\text {th }}$ September 2019

Accepted for Publication: $7^{\text {th }}$ October 2019 


\section{Case Report}

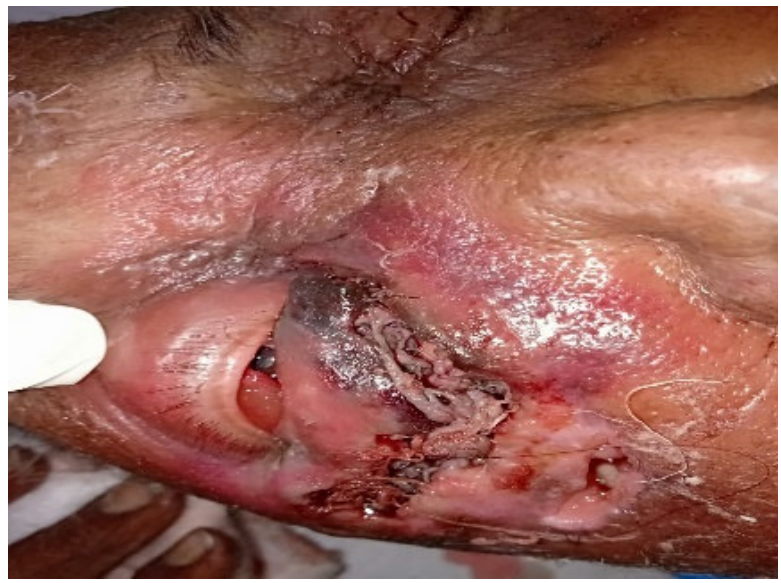

Fig-1: 70-year-old male with Orbital Myiasis right eye.

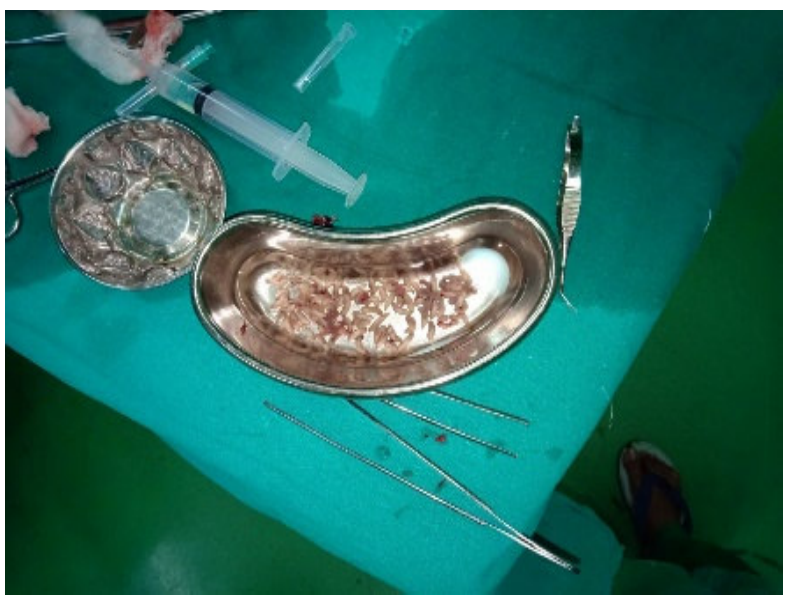

Fig-2: Maggots removed from orbital tissue kept in a kidney tray containing turpentine solution.

Vaccination for clostridium tetani was performed. On the day of admission after consent, under sedation the right orbital wound tissue debridement was done. 82 larvae were removed and kept in turpentine solution. All necrotic tissue removed, and a thorough saline was given. During postoperative period patient remained under intensive supervision and on day 2 of admission 2 to 3 larvae were removed from the wound bedside. Systemic analgesics and antibiotics were given. As the wound began to heal with no larvae seen and as the patient's general condition improved, he was discharged after 5 days.

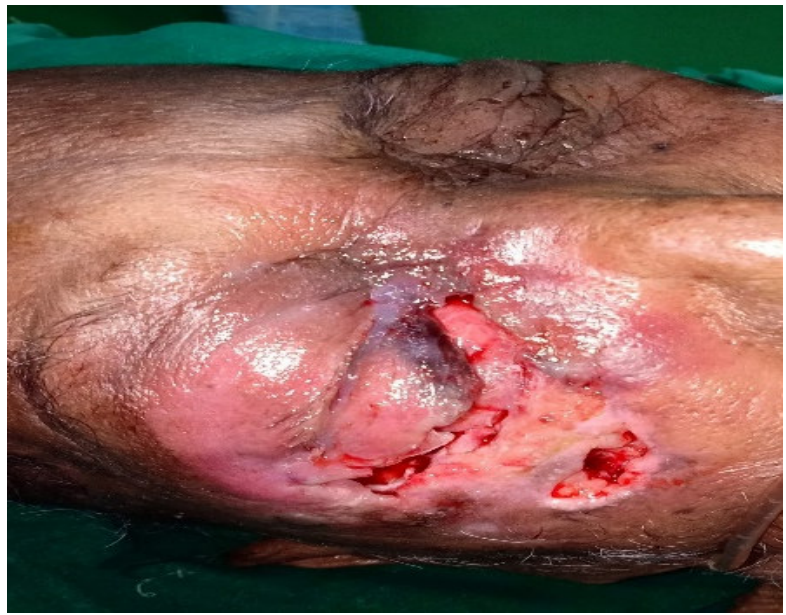

Fig-3: After tissue debridement and removal of maggots. 


\section{Discussion}

The term myiasis was first introduced by Hope which means invasion of living tissue of human beings or other mammals by the eggs or larvae or flies of the Orthopoda order of Diptera [1].

Eye and orbit invasion by a larva of flies commonly seen in tropical countries with low standards of hygiene [2]. Keyt first reported a case of human ocular myiasis in 1900 [3] and Elliot reported a first case of human ocular myiasis in 1910 [4]. The term myiasis is derived from the Greek work 'myia' meaning fly [6]. Myiasis in human beings is rare but as mentioned earlier it is more commonly seen in people with tropical or subtropical countries with poor hygiene, low socio-economic status, with preexisting malignant disease, surgery, ischaemia and those with psychiatric illnesses.

Oestrus ovis (sheep botfly) causes most cases of orbital myiasis. Diptera or true flie are a large order containing $2,40,000$ insects. Life cycle of a fly includes eggs, larvae, pre-pupa and adult flies. Larva or the maggot is the main feeding stage during which it grows from $2 \mathrm{~mm}$ to $15 \mathrm{~mm}$ in length in approximately 4 days [6].

Dermatobia Hominis (human boat fly) and Cordylobia anthropophaga (Tumbu fly) are the most common flies worldwide which cause human infestation. Ophthalmomyiasis this term involves the eye, orbit and periorbital tissues [7]. Hypoderma bovis (hornet fly) which usually infests the cattle and Wohlfahritia magnifica (flesh fly) are the parasites most commonly affecting the eye and the orbit $[2,8]$.

Ophthalmomyiasis is very rarely seen in human beings but can be life-threatening. Depending upon the site of larval infestations, Ophthalmomyiasis is classified into external and internal. External Ophthalmomyiasis includes infestation of superficial periocular tissue and is further divided into palpebral or conjunctival myiasis.

In internal myiasis larvae penetrate the sclera and conjunctival and reach sub-retinal space. These larvae invade and destroy the tissue leading to complications from minor ocular irritation to blindness $[9,10]$.

Larvae penetration into mucosal sinuses and their intracranial invasion can be life-threatening. Penetration of the larva through the fibrous portion of the fontanel causing neonatal fatal cerebral myiasis has been reported [11]. Orbital myiasis is also seen in cases of basal cell carcinoma $[12,13]$.
O. ovis is the most common fly species involved in the Ophthalmomyiasis besides this other less common flies involved in causing it are Caliphora, Lucilla, Sarcophaga, Gastrophillus, Hypoderma, Musca, Wohlfahrtia, cochliomyia, Chrysomya, cuterebra Dermatobia, etc [14]. The natural hosts for O. Bovis are cattle, sheep, deer, rodents, horse and human is an accidental host for it.

Stream of first instar larvae are ejected into the nostrils or eyes of these animal host by a gravid female fly and these larvae later mature in the mucus membrane. Later they are sneezed out and pupate in the soil [15]. The larvae use their pointed hooks to hold on to the mucus membrane in human host. Intact skin or a mucus membrane can be penetrated by the larvae. Infestation occurs by contaminated fingers of the patient after handling the infested cattle or the fly itself [2]. O. Ovis larvae survive for about ten days and later die off in human host.

Pain, redness, itching, burning, tearing are the symptoms seen in Ophthalmomyiasis in the affected eye along with the sensation of crawling or a moving body. Sometimes people especially those with psychiatric illness fail to recognize the insect crawling in their tissue. The symptoms of Ophthalmomyiasis depend upon the severity and extent of the tissue invasion which varies from conjunctivitis to ulceration and hemorrhage.

Hypoderma bovis, Dematobia Hominis and rarely $\mathrm{O}$. Bovis penetrate eye and hence their identification and prompt removal was crucial [16].

To delineate the extent of orbital involvement and exclude intranasal and intra cranial spread the contrast enhanced computed tomography or magnetic resonance imaging of the orbit and brain is useful [17]. Orbital myiasis management includes simple manual removal of maggots to destructive surgeries of the globe and the orbit [18].

The major step is minor ophthalmomyiasis is the manual removal of larvae under the local anesthesia followed by the saline irrigation of the conjunctival sac and the involved tissue.

Solutions like turpentine, hydrogen peroxide, ether, chloroform, and ethanol can be used for easy removal of the maggots [19]. Ivermectin has been used successfully as a non-invasive means to treat orbital myiasis. In case 


\section{Case Report}

of a massive orbital invasion by maggots, prior to surgical debridement, anti-parasitic agent ivermectin can be used to prevent destructive surgery and to ease the mechanical removal of the larvae [20].

Toothed forceps or cotton swabs should be used for removal of maggots. Care should be taken not to induce any laceration while removing these larvae.

To prevent the secondary infection of the affected tissue systemic broad-spectrum antibiotics are recommended. Affected tissue to be examined carefully on follow up visits to detect if any larva remaining or migrating internally [21].

\section{Conclusion}

Orbital myiasis is a rare condition which is commonly seen in people living in a crowded environment with low socio-economic status and poor personal hygiene, old debilitated patients who live in remote rural areas where one cannot get a prompt medical help. It is seen in people with psychiatric illness who are ignorant of the tissue infestation by larvae.

Ophthalmomyiasis caused by fly larvae progresses rapidly and can destroy the orbital tissue rapidly in few days, so it needs the prompt treatment with tissue debridement and mechanical removal of larvae.

Destructive surgeries like enucleation or orbital exenteration may be required in case of extensive orbital myiasis.

\section{Funding: Nil, Conflict of interest: Nil \\ Permission from IRB: Yes}

\section{References}

1. Baliga MJ, Davis P, Rai P, Rajasekhar V. Orbital myiasis: a case report. Int J Oral Maxillofac Surg. 2001; 30 (1):83-84. doi: 10.1054/ijom.2000.0007

2. Agarwal DC, Singh B. Orbital myiasis--a case report. Indian J Ophthalmol. 1990;38(4):187-188.

3. Yeung JC, Chung CF, Lai JS. Orbital myiasis complicating squamous cell carcinoma of eyelid. Hong Kong Med J. 2010;16(1):63-65.

4. Sesterhenn AM, Pfützner W, Braulke DM, Wiegand S, Werner JA, Taubert A. Cutaneous manifestation of myiasis in malignant wounds of the head and neck. Eur J Dermatol. 2009;19(1):64-68. doi: 10.1684/ejd.2008. 0568. Epub 2008 Dec 5.
5. Maurya RP, Mishra D, Bhushan P, Singh VP, Singh MK. Orbital myiasis: due to invasion of larvae of flesh fly (Wohlfahrtia magnifica) in a child; rare presentation. Case Rep Ophthalmol Med. 2012;2012. 371498. doi: 10.1155/2012/371498. Epub 2012 Feb 1.

6. Khataminia G, Aghajanzadeh R, Vazirianzadeh B, Rahdar M. Orbital myiasis. J Ophthalmic Vis Res. 2011 Jul; 6(3):199-203.

7. Burns DA. Diseases caused by arthropods and other noxious animals. Rook's textbook of dermatology. $8^{\text {th }}$ ed; 2004:1555-1618.

8. Mathur SP, Makhija JM. Invasion of the orbit by maggots. The British journal of ophthalmology. 1967; 51 (6): 406-407. doi: 10.1136/bjo.51.6.406.

9. Sachdev MS, Kumar H, Roop, Jain AK, Arora R, Dada VK. Destructive ocular myiasis in a noncompromised host. Indian J Ophthalmol. 1990; 38 (4): 184-186.

10. Weinand FS, Bauer C. [Ophthalmomyiasis externa acquired in Germany: case report and review of the literature]. Ophthalmologica. 2001;215 (5):383-386. doi: 10. 1159/000050891

11. Cestari TF, Pessato S, Ramos-e-Silva M. Tungiasis and myiasis. Clin Dermatol. 2007;25(2):158-164. doi: 10. 1016/j.clindermatol.2006.05.004.

12.Sardesai V,Omchery A, Trasi S. Ocular myiasis with basal cell carcinoma. Indian journal of dermatology. 2014;59 (3): 308-309. doi: 10.4103/0019-5154. 131431.

13. Raina UK, Gupta M, Kumar V, Ghosh B, Sood R, Bodh SA. Orbital myiasis in a case of invasive basal cell carcinoma. Oman J Ophthalmol. 2009;2(1):41-42. doi: 10.4103/0974-620X.48422.

14. Khurana S, Biswal M, Bhatti HS, Pandav SS, Gupta A, Chatterjee SS, et al. Ophthalmomyiasis: three cases from North India. Indian J Med Microbiol. 2010;28(3) : 257-261. doi: 10.4103/0255-0857.66490.

15. Sreejith RS, Reddy AK, Ganeshpuri SS, Garg P. Oestrus ovis ophthalmomyiasis with keratitis. Indian J Med Microbiol. 2010; 28 (4): 399-402. doi: 10.4103/ 0255-0857.71846.

16. Denion E, Dalens PH, Couppié P, Aznar C, SainteMarie D, Carme B, et al. External ophthalmomyiasis caused by Dermatobia hominis. A retrospective study of 


\section{Case Report}

nine cases and a review of the literature. Acta Ophthalmol Scand. 2004;82(5):576-584. doi: 10.1111/j. 1600-0420.2004.00315.x.

17. Pandey TR, Shrestha GB, Kharel R, Shah D. A case of orbital myiasis in recurrent eyelid basal cell carcinoma invasive into the orbit. Case Rep Ophthalmol Med. 2016; 2904346, 4. doi: http://dx.doi.org/ 10.1155/ $2016 / 2904346$

18. Gunalp I, Gündüz K. Duruk K. Orbital exenteration: an review of 429 cases. Int Ophthalmol. 1995;19 (3):177-184. doi: https://doi.org/10.1007/BF00133735.
19. Kersten RC, Shoukrey NM, Tabbara KF. Orbital myiasis. Ophthalmol. 1986;93(9):1228-1232, 1986.

20. Osorio J, Moncada L, Molano A, Valderrama S, Gualtero S, Franco-Paredes C. Role of ivermectin in the treatment of severe orbital myiasis due to Cochliomyia hominivorax. Clinical infectious diseases. 2006; 43 (6): e57-e59. doi: https://doi.org/10.1086/507038.

21. Rao S, Radhakrishnansetty N, Chandalavada H, Hiremath C. External Ophthalmomyiasis by Oestrus ovis: A case report from Davangere. J Lab Physicians. 2018; 10(1):116-117. doi: 10.4103/JLP.JLP_18_17.

\section{How to cite this article?}

Choudhari P, Naik V, Raiturcar T, Usgaonkar U. A case report: orbital myiasis. Trop J Ophthalmol Otolaryngol.2019; 4(6):360-364. doi:10.17511/jooo.2019.i06.02 